\title{
ANALYSIS OF CALPASTATIN AND CALLIPYGE GENES POLYMORPHISM IN PRYDNIPROVSKA MEAT SHEEP
}

\author{
I. A. Pomitun ${ }^{1}$, V. I. Rossokha ${ }^{1}$, Ye. A. Boyko ${ }^{1}$, \\ O. E. Guzevatyi ${ }^{2}$, M. V. Shpilka ${ }^{1}$, R. O. Kulibaba ${ }^{1}$ \\ ${ }^{1}$ Institute of Animal Science, NAAS \\ 1-A, Tvarynnykiv Str., Kharkiv, 61026, Ukraine \\ ${ }^{2}$ National Academy of Agrarian Sciences of Ukraine, \\ 9, Mykhailo Omelyanovich-Pavlenko Str., Kyiv, 01010, Ukraine \\ E-mail:pomitun@ukr.net,rossokha.v@ukr.net*,eabojko@ukr.net,oleg_guzevatiy@ukr.net, \\ shpilkamaxim@gmail.com,romankx37@gmail.com
}

Received April 05, 2019 / Received May 10, 2019 / Accepted July 19, 2019

\begin{abstract}
Aim. To study calpastatin $(C A S T)$ and callipyge $(C L P G)$ genes polymorphism in Prydniprovska meat sheep. Methods. The studies were conducted using PCR-RFLP method. DNA was isolated from 47 animals. The amplicons were treated with restriction endonucleases MspI and FaqI for genes $C A S T$ and $C L P G$, respectively. Results. The study determined the polymorphism of CAST gene fragment. Two alleles - M (336, 286 b.p.) and $\mathrm{N}$ (622 b.p.) with the frequency of 0.83 and 0.17 , respectively, were detected. The frequency of genotypes was as follows: $\mathrm{MM}-0.77, \mathrm{MN}-0.13$ and $\mathrm{NN}-0.10$. There was a noted tendency towards the increase in live bodyweight of 4-month-old lambs, carriers of $\mathrm{N}$ allele (genotypes $\mathrm{NN}$ and $\mathrm{MN}$ ), compared to the index for the lambs of the same age with genotype MM. Locus CLPG was monomorphic, only allele A was determined (278, 117 and 31 b.p.). Allele $\mathrm{G}$ with the mutation, manifested in muscle hypertrophy phenotype, was not detected, all the animals under investigation had genotype AA. Conclusions. CAST gene polymorphism was determined in Prydniprovska meat sheep during our work. The tendency towards the increase in live bodyweight of 90-day-old lambs, carriers of allele $\mathrm{N}$, was established which demonstrated promising perspectives of further studies on associations of this gene and meat qualities of Prydniprovska meat sheep. The obtained results on the monomorphic nature of locus CLPG and the absence of mutation, related to muscle hypertrophy phenotype, demonstrated that the mutation of this gene may be built into the genome of domestic breeds of sheep only via cross-breeding with foreign breeds, in which this trait is manifested.
\end{abstract}

Keywords: sheep, gene, meat productivity, calpastatin, callipyge, polymorphism, Prydniprovska meat breed.

DOI: https://doi.org/10.15407/agrisp6.02.058

\section{INTRODUCTION}

The innovations of molecular genetics have recently been widely used in animal science, allowing scientists to identify the genes, directly or indirectly related to productivity $[1,2]$. Most economically valuable traits are known to be polygenetic, and their manifestation depends on the impact of environmental factors. At the same time, there are main genes of quantitative traits (candidate genes), whose contribution into the manifestation of a specific trait is decisive [3]. The review of references related to candidate genes, responsible for economically valuable traits of sheep, demonstrated

(C) I. A. POMITUN, V. I. ROSSOKHA, YE. A. BOYKO,

O. E. GUZEVATYI, M. V. SHPILKA, R. O. KULIBABA, 2019 that the impact of about 50 target genes on productivity indices was studied to a different degree, including the data on polymorphism and impact of several important genes on meat productivity [4-6]. Calpastatin and callipyge are among them.

Calpastatin is a specific endogenous inhibitor of calpain (neutral calcium-dependent proteinase), playing a decisive role in the regulation of calpain activity in the cell. The rate of skeletal muscle growth mainly depends on three factors: the rate of synthesizing muscle proteins, the rate of muscle protein breakdown and the sizes of skeletal muscles. It was demonstrated that while breaking down relatively small peptide bonds in a number of myofibril proteins, $\mu$ and $\mathrm{m}$ calpains are in- 
volved in their breakdown along with other proteolytic systems. Here a great role of calpains was determined in case of postmortem destruction of muscle proteins. In addition, it was determined that calpain activity is required to synthesize myoblasts; it also plays its role in the processes of signal transduction, participating in the deactivation of kinases and phosphatases [7]. Calpastatin may inhibit the calpain activity by binding its three inhibitory domains A, B, C to the domains of calpains. High activity of calpastatin in the living cell destroys the ability of calpains to degrade the proteins of myofibrils at postmortem storage [8].

Therefore, one may assume that the mutations of CAST gene, leading to the inhibition of its activity (or decrease in calpastatin synthesis) may lead to the increase in calpain activity and therefore the increase in the proliferation of myoblasts in the living cell and greater proliferation of proteins which may have positive impact on quantitative and qualitative indices («meat tenderness») of meat productivity. On the contrary, mutations, leading to the increase in calpastatin activity (or its greater synthesis) would lead to the decrease in calpain activity, reduction in normal skeletal growth and lesser postmortem proteolysis of myofibril proteins. It was actually demonstrated that a high level of CAST gene expression is related to a low value of «meat tenderness» index for lambs [9]. This fact demonstrates the promising perspectives of studying this gene in association with meat characteristics of animals.

CAST gene (GeneID: 443364) in localized on chromosome 5 of sheep, consists of 29 exons and has the size of over 89 thousand 553 b.p. Gene polymorphism is localized on the first intron and may be determined by PCR-RFLP, using MspI endonuclease, two alleles of this gene are revealed here: $M$ and $N$ [10].

Callipyge (CLPG) (from Greek «calli» - wonderful, «pyge» - buttocks) is one of the most wellknown mutations, impacting the development of muscles in sheep, first described in 1983 for a ram in the flock of Dorset sheep, the phenotype of which was characterized by unusual muscle hypertrophy in hind quarters and a small amount of fat and was inherited by the progeny [11]. Here the described muscle hypertrophy occurs after the age of three months [12], thus, there is no increased risk of dystocia for lambs with CLPG. Sheep with CLPG mutation are different from sheep with the genotype, normal by this mutation in terms of a series of economically viable indices: they are characterized by a larger total weight of muscles of the pelvis, torso and fore limbs [13], a higher percentage of meat yield, larger loin, relatively smaller amount of fat in meat $[14,15]$, and lower average daily fodder consumption, which leads to lower production costs during breeding [12]. At the same time, sheep with CLPG were notable for higher meat hardness $[15,16]$.

CLPG mutation is characterized by a special type of non-Mendelian inheritance, called polar superdominance, which lies in the fact that phenotype CLPG is manifested only in the progeny, heterozygous by CLPG-mutation, and the mentioned mutation in this progeny should obligatorily be obtained from the father (genotype clpg ${ }^{\mathrm{Mat}} / \mathrm{CLPG}^{\mathrm{Pat}}$, where ${ }^{\mathrm{Mat}}$ and ${ }^{\mathrm{Pat}}$, respectively, shows maternal or paternal origin of the allele), here three other possible genotypes ( $\operatorname{clpg}^{\text {Mat }} / \mathrm{clpg}^{\text {Pat }}$, $\mathrm{CLPG}^{\mathrm{Mat}} / \mathrm{clpg}^{\mathrm{Pat}}, \mathrm{CLPG}^{\mathrm{Mat}} / \mathrm{CLPG}^{\mathrm{Pat}}$ ) are phenotypically normal [17]. CLPG-mutation was mapped by Cockett et al. (1994) on chromosome 18 of sheep [11].

Due to two independent studies, aimed at studying molecular fundamentals of this mutation, it was determined that CLPG-mutation is the transition of A to $\mathrm{G}$, located in a highly conservative telomere region of a chromosome of 12 b.p., between genes DLK-1 (delta like non-canonical Notch ligand 1) and GTL-2 (gene trap locus 2), containing in the domain the genes DLK1, GTL2, PEG11 (or RTL-1, retrotransposon like 1) and MEG8 (maternally expressed 8 , small nuclear RNA host gene) $[18,19]$.

This region is a regulatory element of a long range, probably, an insulator and enhancer. CLPG-mutation modifies the activity of the general regulatory element, which is responsible for the enhanced expression of genes DLK1, GTL2, PEG11, MEG8 and probably, other non-investigated genes, which initiates the manifestation of CLPG genotype [20]. The key to the mechanism of action of CLPG-mutation is in the changes of DNA methylation, surrounding the mutation site wild type allele is hypermethylated and CLPG allele is hypomethylated. During prenatal development, the methylation of $10 \mathrm{CpG}$ sites, flanking the mutation, is similar to that along the whole genotype, at the same time, it gets doubled during the postnatal development of sheep with normal genotype. Normal postnatal enhanced methylation is considerably expressed in sheep, carrying one or two mutant alleles, and this is related to a high level of DLK1 expression, and possibly, other genes, leading to muscle hypertrophy phenotype [21]. The presence of this mutation is also related to the development of new sites of DNAse hypersensitivity, 
which demonstrates increased relaxation of chromatin state [22].

The interest to the study on polymorphisms of genes $C A S T$ and $C L P G$ of sheep is evident in a great number of works, conducted in 10 recent years using different breeds in different countries [23-27]. At the same time, polymorphism of these genes was not studied in breeds, created in Ukraine.

\section{MATERIALS AND METHODS}

The study was conducted using 47 sheep of Kharkiv intrabreed type of Prydniprovska meat breed (collective farm enterprise «Doslidne», Poltava region). This type of sheep was created by the breeders of the Institute of Animal Breeding, the National Academy of Agrarian Sciences of Ukraine, via cross-breeding of the sheep of Dnipropetrovsk intrabreed type of Askanian meat-wool breed (maternal form) with Olibs and Merinolandschaf breeds (paternal forms) [28].

The DNA was obtained from hair follicles of sheep using the extraction kit DNA-sorb B (AmplySens) in accordance to the manufacturer's instructions.

The analysis of polymorphism of genes CAST and $C L P G$ was conducted by PCR-RFLP. Locus-specific amplification of the fragments of genes CAST (622 b.p.) and $C L P G$ (426 b.p.) was conducted in the automatic regime of the thermocycler AMPLY-4, using the following primers:

\section{F: 5'-TGGGGCCCAATGACGCCATCGATG-3',}

R: 5'-GGTGGAGCAGCACTTCTGATCACC-3' for gene CAST [10],

\section{F: 5'-TGAAAA CGTGAACCCAGAAGC-3' \\ R: 5'-GTCCTAAATAGGTCCTCTCG-3' for CLPG [18].}

The lyophilized preformed set MasterMix (Isogene) was used for amplification. Eppendorf tubes of $0.2 \mathrm{ml}$ from the Isogen set of reagents, containing Taq-polymerase $50 \mathrm{un} / \mathrm{ml}-0.5 \mu \mathrm{l}$, dATP $-400 \mu \mathrm{M}$, dCTP $400 \mu \mathrm{M}, \mathrm{dGTP}-400 \mu \mathrm{M}$, dTTP - $400 \mu \mathrm{M}, \mathrm{MgCl}_{2}-$ $3 \mathrm{mM}$, were introduced $5 \mu \mathrm{l}$ of the investigated DNA solution, $2.5 \mu \mathrm{l}$ of each primer and $10 \mu \mathrm{l}$ of 2 -fold buffer for PCR from the MasterMix set.

The temperature regime of PCR for the amplification of gene fragments was as follows: DNA denaturation at $94{ }^{\circ} \mathrm{C}-5 \mathrm{~min}$, then 35 cycles according to the following scheme: DNA denaturation at $94{ }^{\circ} \mathrm{C}-30 \mathrm{sec}$, annealing of primers at $57{ }^{\circ} \mathrm{C}$ and $58^{\circ} \mathrm{C}$ (for $C A S T$ and $C L P G$, respectively), DNA synthesis at $72{ }^{\circ} \mathrm{C}-1 \mathrm{~min}$ (during the last cycle for $10 \mathrm{~min}$ ).
The restriction of the obtained amplicons was conducted in the reaction mixture with restrictase MspI and FaqI (Thermo Scientific) for $C A S T$ and $C L P G$, respectively, in accordance to the manufacturer's protocols. The reaction mixture was incubated in the thermostat at $37^{\circ} \mathrm{C}$ for $6 \mathrm{~h}$. The results of PCR product splitting using restrictases was estimated by electrophoretic method in $3 \%$ agarose gel, stained with ethidium bromide using the transilluminator in UV light.

The living bodyweight of lambs was determined by weighing them on the electronic scales with the precision of up to $0.1 \mathrm{~kg}$ at weaning, at the age of 90 days and 14 months.

The frequencies of alleles and genotypes were estimated according to the results of molecular-genetic analysis. The analysis of reliability of the differences between the live bodyweight of lambs of different groups was conducted using Student's $t$-criterion [29].

\section{RESULTS}

The studies demonstrated that the fragment of CAST gene in Prydniprovska meat sheep breed by this mutation was polymorphic. After the restriction of amplicons (622 b.p.), two alleles $\mathrm{M}$ (336, 286 b.p.) and $\mathrm{N}$ (622 b.p.) were found along with three genotypes: MM, $\mathrm{MN}$ and NN (Fig. 1). The frequency of allele $\mathrm{M}$ was $0.83, \mathrm{~N}-0.17$. The frequency of genotypes was as follows: $\mathrm{MM}-0.77, \mathrm{MN}-0.13$ and $\mathrm{NN}-0.10$.

While changing the live bodyweight of lambs at the moment of weaning at the age of 90 days, there was a tendency $(\mathrm{P}>0.05)$ towards its increase in female sheep of one shear with genotypes MN and NN compared to the MM sheep of the same age. The corresponding indices were $25.0 \pm 1.00$ and $22.7 \pm 1.43 \mathrm{~kg}$. A similar tendency was also observed for male sheep. A small number of animals-carriers of $\mathrm{N}$ allele may have prevented the determination of considerable differences between the investigated groups. While measuring the index of live bodyweight of female sheep of one shear at the age of 14 months, no reliable differences were found between different genotypes. For instance, the index of live bodyweight for female sheep of one shear with genotypes $\mathrm{MN}$ and $\mathrm{NN}$ was $56.7 \pm 3.33$, and for the sheep of their age (genotype MM) $-57.4 \pm 1.73$.

The study on polymorphism of CLPG locus in Prydniprovska meat sheep breed determined that it was monomorphic by this mutation. After the restriction of amplicons (426 b.p.), only allele A was revealed (the presence of fragments of 278, 117 and 31 b.p. on the electrophoregram). Allele $\mathrm{G}$ (fragments of 395 and 31 


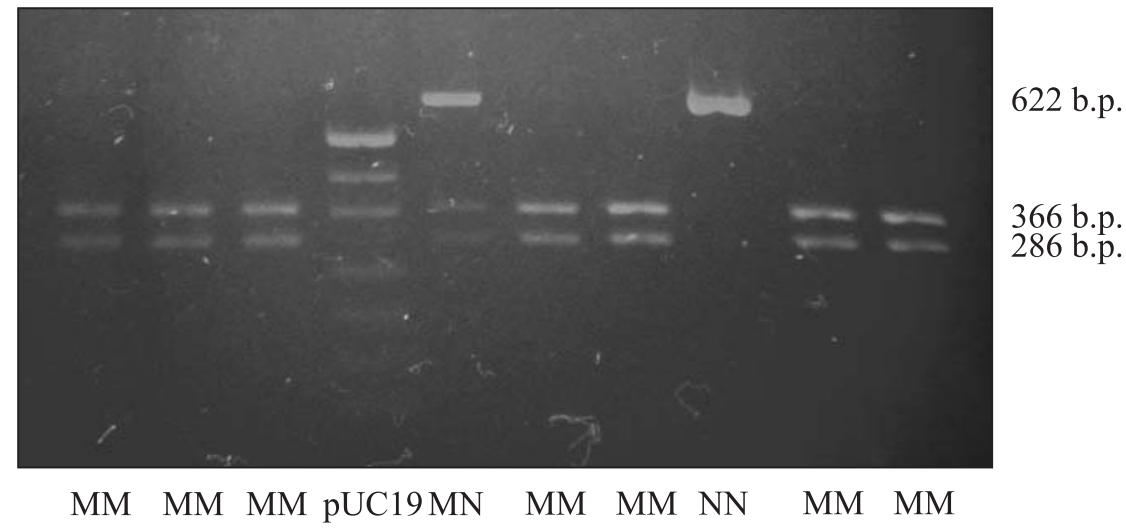

Fig. 1. The electrophoregram of restriction products of CAST gene fragment in Prydniprovska meat sheep breed. Note: genotype MM - 336, 286 b.p., MN - 622, 336, 286 b.p., NN - 622 b.p., molecular mass marker pUC19 DNA/MspI (HpaII): 501, 404, 331, 242, 190, 147, 111 b.p.

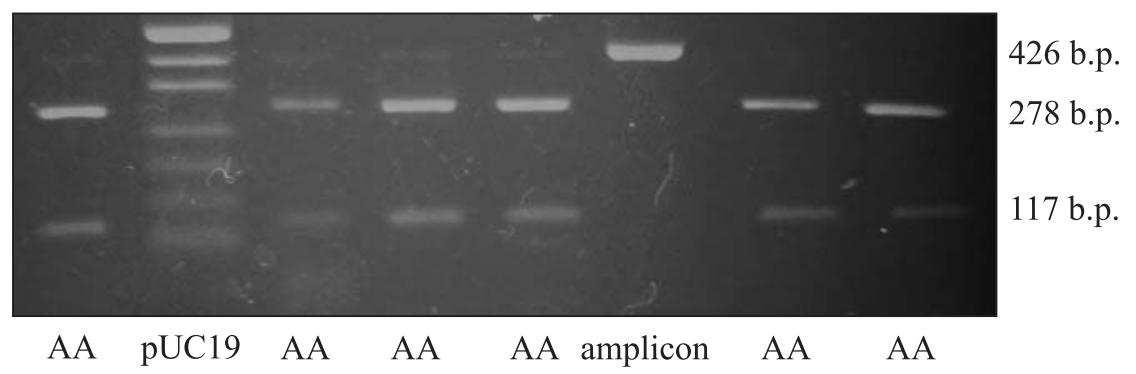

Fig. 2. The electrophoregram of restriction products of $C A S T$ gene fragment in Prydniprovska meat sheep breed. Note: amplicon - 426 b.p., genotype AA - 278, 117 b.p., molecular mass marker pUC19 DNA/MspI (HpaII): 501, 404, 331, 242, 190, 147,111 b.p.

b.p.) with the mutation, leading to muscle hypertrophy phenotype, was not found. All the investigated animals of this breed had genotype AA (Fig. 2).

\section{DISCUSSION}

The results of the study on CAST gene polymorphism in Prydniprovska meat sheep breed demonstrate that the obtained data about the frequencies of alleles $\mathrm{M}$ and $\mathrm{N}$ of this gene are similar to the results, found by other authors for different breeds of sheep.

For instance, the work [25] presents the analysis of studies about the content of $\mathrm{M}$ and $\mathrm{N}$ alleles in different breeds of sheep. The frequencies of alleles were analyzed for the following breeds from Turkey - Gökçeada, Kivircik, Karacabey Merino, Indonesia - Jastru, Pakistan - Balkhi, Kajli, India - Bandur, Iran - Lori, Bulgaria - SPBM (Synthetic Population Bulgarian Milk), breeds of Poland - Polish Merino, France - Berrichondu Cher, Ilede France, Germany - Blackheaded Mutton, Iran - Karacabey Merino, Sanjabi, Afshari, Ghezel, Makui, Arkhamerino, Mehraban, Saudi Arabia - Najdi, Harri. A number of works, which have not been included into this review, also studied the frequency of the mentioned alleles of CAST gene in the breeds of Iran - Zandi [30], Dalagh [31], Pakistan - Kajli, Lohi, Thalli [32], Egypt - Barki, Ossimi, Rahmani, Sub-total [26], Turkey - Kivircik [24] and Askanian caracul breed with prolificacy, bred in Ukraine [33]. In all the investigated breeds, the frequency of allele $\mathrm{M}$ exceeded that of allele $\mathrm{N}$ considerably and was in the range of $0.63-0.99$, therefore, the frequency of allele $\mathrm{N}$ was in the range from 0.01 to 0.37 . Rather a high frequency of allele $\mathrm{N}(0.45)$ was found for Dalagh breed in Iran [31]. At the same time, Iranian breeds Arkhamerino and Mehraban were characterized by a higher frequency of allele $\mathrm{N}$ compared to $\mathrm{M}$. The frequencies of alleles $\mathrm{M}$ and $\mathrm{N}$ for Arkhamerino breed were 0.48 and 0.52 , and those of Mehraban breed -0.33 and 0.67 , respectively [34].

Therefore, the polymorphism of this CAST gene fragment was determined for the investigated sheep breeds, in most breeds the frequency of allele $\mathrm{M}$ exceeded that of allele $\mathrm{N}$ considerably, the same specificity was remarkable for Prydniprovska meat breed as well. 
The analysis of works about the association of different allelic variants of CAST gene with economically valuable traits demonstrates that most of them were conducted using single-strand conformation polymorphism (PCR-SSCP) analysis. This method allowed determining 3 alleles $-\mathrm{a}, \mathrm{b}$ and $\mathrm{c}-$ of this gene, and the association of some genotypes by these alleles with meat traits - live bodyweight gain $[35,36]$, the level of water loss in meat $[36,37]$, shares of shoulder blade was demonstrated.

There are some studies about the association of the alleles under our investigation ( $\mathrm{M}$ and $\mathrm{N}$, determined by PCR-RFLP) of CAST gene with the indices of meat productivity of sheep. For instance, in the article [25] Russian researchers used Salsk breed to demonstrate that heterozygotes $\mathrm{MN}$ were characterized with higher daily gain from birth to two months. Similar results (prevalence of MN heterozygotes) were observed for Pakistan breeds Balkini by the index of daily gain from birth to 4 months, and Kajli - the same index up till 8 months [39] and Jordanian breed Awassi - by the index of daily gain and live bodyweight at the age of 70 days, and the indices of meat quality [40]. At the same time, it was demonstrated for Turkish breed Kivircik that the content of fat in sheep with genotype NN was lower compared to MM and MN [24].

The data, obtained by us, demonstrating the tendency towards the increase in live bodyweight of 90-day-old lambs for the carriers of allele $\mathrm{N}$ ( $\mathrm{NN}$ and $\mathrm{MN}$ ) compared to the index for lambs with genotype MM, are in agreement with the results of the abovementioned studies which shows the promising perspectives of further work with this breed in the area of practical breeding in terms of improving meat indices using the obtained data about the polymorphism of CAST gene.

The analysis of references regarding the study of the polymorphism of CLPG locus in sheep demonstrates that the discovery of this mutation in Dorset breed and wide application of PCR-RFLP in molecular genetics for the purpose of revealing it led to the search for CLPG mutation in sheep of other breeds. However, this mutation was not determined in all the articles, known to us, all the animals had a normal genotype. For instance, the absence of PCR-RFLP of CLPG polymorphism was absent in populations of such breeds as Dorset and Suffolk, and their hybrids with local Chinese breed of sheep - Xinjiang Fine Wool [41], breed Lori (Iran) [42, 43], breed Karnobat Merino (Bulgaria) [44], breed Karakachan (Bulgaria) [27], breeds Najdiand, Harri (Saudi Arabia) [45], breeds Tsigai, Improved Valachian, East
Friesian, Lacaune (Slovakia) [23]. A large number of articles about the study on the nature of CLPG-mutation, the explanation of the mechanisms of their inheritance, which have been cited above [17-22] were conducted in the framework of a specific ram of Solid Gold of Dorset breed, in which the mutation was first revealed. Therefore, the data, obtained by us about the absence of the polymorphism of CLPG locus in Prydniprovska meat sheep, are in agreement with the data, obtained regarding other breeds, and demonstrate that the introduction of CLPG-mutation in the breeds of Ukrainian sheep is possible only with Dorset breed from the households where it was revealed and is preserved.

\section{CONCLUSIONS}

The polymorphism of calpastatin and callipyge genes was studied in sheep of Kharkiv intrabreed type of Prydniprovska meat breed. It was demonstrated that CAST locus is polymorphic in this breed. In terms of this mutation, two alleles $\mathrm{M}$ and $\mathrm{N}$ were determined with the frequency of 0.83 and 0.17 , respectively.

While studying the live bodyweight of 90-day-old lambs, there was a revealed tendency towards its increase for the carriers of allele $\mathrm{N}$ ( $\mathrm{NN}$ and $\mathrm{MN}$ ) compared to the index for lambs of the same age with genotype MM, which shows the promising perspectives of further work with this breed in the area of practical breeding in terms of improving meat indices using the obtained data about the polymorphism of CAST gene.

The study on CLPG locus in Prydniprovska meat sheep breed demonstrated that it was monomorphic by the investigated mutation. Only the allele of normal development - A - was determined, all the investigated animals of this breed had genotype AA. Allele G with the mutation, leading to muscle hypertrophy phenotype, was not found. The migration of CLPG-mutation into the population of Prydniprovska meat sheep breed is possible only due to cross-breeding with Dorset breed from foreign households, where it was revealed and is preserved. This may serve further improvement of the coefficient of meatiness and quality of mutton.

\section{Аналіз поліморфізму генів калпастатину і калліпігії у овець придніпровської м'ясної породи}

I. А. Помітун ${ }^{1}$, В. I. Россоха ${ }^{1}$, О. А. Бойко ${ }^{1}$, О. Є. Гузеватий ${ }^{2}$, М. В. Шпилька ${ }^{1}$, Р. О. Кулібаба ${ }^{1}$

${ }^{1}$ Інститут тваринництва НААН, вул. Тваринників 1-А, м. Харків, 61026, Україна,

${ }^{2}$ Національна академія аграрних наук України вул. Михайла Омеляновича-Павленка, 9 , м. Київ, 01010, Україна, 
e-mail: pomitun@ukr.net, rossokha.v@ukr.net*,eabojko@ ukr.net,oleg_guzevatiy@ukr.net, shpilkamaxim@gmail. com, romankx37@gmail.com

Мета. Вивчення поліморфізму генів калпастатіна (CAST) і калліпігії (CLPG) у овець придніпровської м'ясної породи. Методи. Дослідження проводили з використанням методу PCR-RFLP. ДНК виділена у 47 тварин. Амплікони оброблені ендонуклеазами рестрикції MspI i FaqI для генів CAST і CLPG, відповідно. Результати. В результаті досліджень встановлено поліморфізм фрагмента гена CAST. Виявлено 2 алелі М (336, 286 п.н.) та $\mathrm{N}$ (622 п.н.) з частотою 0,83 і 0,17, відповідно. Частота генотипів ММ складала $0,77, \mathrm{MN}-0,13$ i NN - 0,10. Відзначено тенденцію до збільшення живої маси ягнят у віці 4 місяців у носіїв алелі $\mathrm{N}$ (генотипи $\mathrm{NN}$ і MN) в порівняння 3 показником однолітків 3 генотипом МM. Локус CLPG був мономорфний, виявлено тільки алель А $(278,117$ і 31 п.н.). Алелі G 3 мутацією, яка проявляється гіпермускульним фенотипом, виявлено не було, всі досліджувані тварини імені генотип АА.

Висновки. У роботі встановлено поліморфізм гена CAST у овець придніпровської м'ясної породи і тенденція до збільшення живої маси ягнят у віці 90 днів у носіїв алелі $\mathrm{N}$, що свідчить про перспективність подальшої роботи $з$ вивчення асоціацій цього гена 3 м'ясними якостями овець придніпровської м'ясної породи. Отримані результати про мономорфності локусу CLPG i відсутності мутації, пов'язаної з гіпермускульним ефектом свідчать про те, що мутація цього гена можливо вбудована в геном вітчизняних порід овець лише завдяки схрещуванню з зарубіжними породами, в яких вона проявляється.

Ключові слова: вівці, ген, м'ясна продуктивність, калпастатін, калліпігія, поліморфізм, придніпровська м'ясна порода.

\section{Анализ полиморфизма генов калпастатина и каллипигии у овец приднепровской мясной породы}

И. А. Помитун ${ }^{1}$, В.И. Россоха ${ }^{1}$, Е. А. Бойко ${ }^{1}$, О. Е. Гузеватый ${ }^{2}$, М. В. Шпилька ${ }^{1}$, Р. А. Кулибаба ${ }^{1}$

${ }^{1}$ Институт животноводства НААН,

ул. Животноводов 1-А, г. Харьков, 61026, Украина

${ }^{2}$ Национальная академия аграрных наук Украины, ул. Михаила Омеляновича-Павленка, 9, г. Киев, 01010 , Украина

e-mail:pomitun@ukr.net, rossokha.v@ukr.net*,eabojko@ ukr.net,oleg_guzevatiy@ukr.net, shpilkamaxim@gmail. com, romankx37@gmail.com

Цель. Изучение полиморфизма генов калпастатина (CAST) и каллипигии (CLPG) у овец приднепровской мясной породы. Методы. Исследования проводили с использованием метода PCR-RFLP. ДНК выделена у
47 животных. Ампликоны обработаны эндонуклеазами рестрикции MspI и FaqI для генов CAST и CLPG, соответственно. Результаты. В результате исследований установлен полиморфизм фрагмента гена CAST. Выявлено 2 аллеля М (336, 286 п.н.) и N (622 п.н.) с частотой 0,83 и 0,17 , соответственно. Частота генотипов МM составляла $0,77, \mathrm{MN}-0,13$ и $\mathrm{NN}-0,10$. Отмечена тенденция к увеличению живой массы ягнят в возрасте 4 месяцев у носителей аллеля $\mathrm{N}$ (генотипы $\mathrm{NN}$ и $\mathrm{MN}$ ) в сравнение с показателем сверстников с генотипом МM. Локус CLPG был мономорфным, выявлен только аллель A $(278,117$ и 31 п.н.). Аллеля G с мутацией, которая проявляется гипермускульным фенотипом, выявлено не было, все исследуемые животные имени генотип AА. Выводы. В работе установлен полиморфизм гена CAST у овец приднепровской мясной породы и выявлена тенденция к увеличению живой массы ягнят в возрасте 90 дней у носителей аллеля $\mathrm{N}$, что свидетельствует о перспективности дальнейшей работы по изучению ассоциаций этого гена с мясными качествами овец приднепровской мясной породы. Полученные результаты о мономорфности локуса CLPG и отсутствии мутации, связанной с гипермускульным эффектом, свидетельствуют о том, что мутация этого гена может быть встроена в геном отечественных пород овец лишь благодаря скрещиванию с зарубежными породами, в которых она проявляется.

Ключевые слова: овцы, ген, мясная продуктивность, калпастатин, каллипигия, полиморфизм, приднепровская мясная порода.

\section{REFERENCES}

1. Wakchaure $R$, Ganguly $S$, Praveen PK, Kumar A, Sharma S, Mahajan T. Marker-Assisted Selection (MAS) in Animal Breeding: A Review. J. Drug Metabol. Toxicol. 2015; 6(5):1-4. https://doi.org/10.4172/2157-7609. $1000 \mathrm{e} 127$.

2. Zhi-Liang Hu, Park CA, Reecy JM. Developmental progress and current status of the animal QTLdb. Nucl. Acid. Res. 2016;44(1):827-33. https://doi.org/10.1093/ nar/gkv1233.

3. Glazko TT, Komarov AV, Borzakovskaja EV. DNAtechnologies to improve meat productivity. Izvestiya TSHA. 2008;1:75-80 (in Russian).

4. Pomitun IA, Boyko YeA, Rossokha VI. Genes, determining productive qualities and resistance to diseases of sheep. Scientific-technical bulletin of the Institute of Animal Breeding. 2011;104:173-82 (in Ukrainian). http://animal.kharkov.ua/archiv/ntb/NTB\%20104.pdf

5. Trukhachev VI, Selionova MI, Krivoruchko AYu, Aibasov $A M M$. Genetic markers of meat productivity of sheep (Ovis Aries L.). I. Myostatin, Calpain, Calpastatin (Review). Sel'skokhozyaistvennaya Biologiya. 2018;53 (6):1107-19. https://doi.org/10.15389/agrobiology.2018. 6.1107 eng. 
6. Abiye Shenkut Abebe, Mengistie Taye. A Review on the Genetic Basis of Growth and Prolificacy Traits in Sheep. Int. J. Anim. Res. 2019;4(25):1-8.

7. Goll DE, Thompson VF, Taylor RG, Ouali A. The calpain system and skeletal muscle growth. Can. J. Anim. Sci. 1998;78:503-12. https://doi.org/10.4141/A98-081.

8. WendtA, Thompson VF, GollDE. Interaction of calpastatin with calpain: a review. Biol. Chem. 2004;385(6):465-72. https://doi.org/10.1515/bc.2004.054.

9. Bagatoli A, Gasparino E, Soares MA, Amaral RM, Macedo FA, Voltolini DM, Del Vesco AP. Expression of calpastatin and myostatin genes associated with lamb meat quality. Genet. Mol. Res. 2013;12(4):6168-75. doi: 10.4238/2013.December.4.3.

10. Palmer BR, Roberts N, Hickford JG, Bickerstaffe R. Rapid communication: PCR-RFLP for MspI and NcoI in the ovine calpastatin gene. J. Anim. Sci.1998;76(5):1499500. https://doi.org/10.2527/1998.7651499x.

11. Cockett NE, Jackson SP, Shay TL, Nielsen D, Moore SS, Steele MR, Barendse W, Green RD, Georges M. Chromosomal localization of the Callipyge gene in sheep (Ovis aries) using bovine DNA markers. Gene-tics. 1994;91(8):3019-23. https://doi.org/10.1073/pnas.91.8. 3019.

12.Jackson SP, Green RD, Miller MF. Phenotypic characterization of Rambouillet sheep expressing the callipyge gene: i. inheritance of the condition and production characteristics. J. Anim. Sci. 1997;75(1):14-8. https://doi. org $/ 10.2527 / 1997.751133 x$.

13. Jackson SP, Miller MF, Green RD. Phenotypic characterization of Rambouillet sheep expressing the callipyge gene: ii. carcass characteristics and retail yield. J. Anim. Sci. 1997;75(1):125-32. https://doi.org/10.2527/ 1997.751125x .

14.Jackson SP, Miller MF, Green RD. Phenotypic characterization of rambouillet sheep expressing the callipyge gene: iii. muscle weights and muscle weight distribution. J. Anim. Sci. 1997;75(1):133-138. https:// doi.org/10.2527/1997.751133x.

15. Koohmaraie M, Shackelford SD, Wheeler TL, Lonergan $S M$, Doumit ME. A muscle hypertrophy condition in lamb (Callipyge): characterization of effects on muscle growth and meat quality traits. J. Anim. Sci. 1995;73(12):3596607. https://doi.org/10.2527/1995.73123596x.

16. Shackelford SD, Wheeler TL, Koohmaraie M. Effect of the callipyge phenotype and cooking method on tenderness of several major lamb muscles. J. Anim. Sci. 1997; 75(8):2100-5. https://doi.org/10.2527/1997.7582-100x.

17. Cockett NE, Jackson SP, Shay TL, Farnir F, Berghmans $S$, Snowder GD, Nielsen DM, Georges M. Polar overdominance at the ovine callipyge locus. Science. 1996; 273(5272):236-8. https://doi.org/10.1126/science.273.5272. 236.

18. Freking BA, Murphy SK, Wylie AA, Rhodes SJ, Keele $J W$, Leymaster KA, Jirtle RL, Smith TPL. Identification of the single base change causing the callipyge muscle hypertrophy phenotype, the only known example of polar overdominance in mammals. Genome Res. 2002;12:1496-506. https://doi.org/10.1101/gr.571002.

19. Smit M, Segers K, Carrascosa LG, Shay T, Baraldi F, Gyapay G, Snowder G, Georges M, Cockett N, Charlier $C$. Mosaicism of Solid Gold supports the causality of a noncoding A-to-G transition in the determinism of the Callipyge phenotype. Genetics. 2003;163(1):453-6. https://doi.org/10.3410/f.1010789.186118.

20. Cockett NE, Bidwell CA, Charlier C, Smit M, Sergers $K$, Shay TL, Karim L, Snowder GD, Georges $M$. Muscle enhanced traits in sheep. Progress in Obesity Research. 2003;9:272-4. http:// books.google.com. ua $>$ books $>$ isbn $=274$...

21. Murphy SK, Nolan CM, Huang Z, Kucera KS, Freking $B A$, Smith TPL, Leymaster KA, Weidman JR, Jirtle RL. Callipyge mutation affects gene expression in cis: a potential role for chromatin structure. Genome Res. 2006;16(3):340-6. doi: 10.1101/gr.4389306.

22. Tellam RL, Cockett NE, Vuocolo T, Bidwell CA. Genes contributing to genetic variation of muscling in sheep. Frontiers in Genetics. 2012;3(164):1-14. https://doi. org/10.3389/fgene.2012.00164.

23. Gábor M, Trakovická A, Miluchová M. Analysis of polymorphism of CAST gene and CLPG gene in sheep by PCR-RFLP method. Zootehnieşi Biotehnologii. 2009;42(2):P. 470-6.

24. Yilmaz O, Cemal İ, Karaca O, Ata N. Association of calpastatin (CAST) gene polymorphism with weaning weight and ultrasonic measurements of loin eye muscle in Kivircik lambs. Kafkas Univ.Vet. Fak. Derg. 2014;20(5):675-680. doi: 10.9775/kvfd.2014.10816.

25. Gorlov IF, Shirokova NV, Randelin AV, Voronkova VN, Mosolova NI, Zlobina EY, Kolosov YA, Bakoev NF, Leonova MA, Bakoev SY, Kolosov AY, Getmantseva $L V$. CAST/MspI gene polymorphism and its impact on growth traits of Soviet Merino and Salsk sheep breeds in the South-European part of Russia. Turkish Journal of Veterinary and Animal Sciences. 2016;40:399-405. doi:10.3906/vet-1507-101.

26. Othman OE, Darwish HR, Abou-Eisha A, El-Din AE. Investigation of calpastatin gene polymorphism in Egyptian sheep and goat breeds. Biosciences Biotechnology Research Asia. 2016;13(4):1879-83. https://doi.org/ $10.13005 / \mathrm{bbra} / 2343$.

27. Dimitrova I, Bozhilova-Sakova M, Iliev M. Study of some genes associated with meat productivity in Karnobat Merino sheep breed using PCR-RFLP. Journal of Agriculture and Veterinary Science (IOSR-JAVS). 2017;10(8, III):61-5.

28. Pomitun IA, Kosova A, Zolotareva SA, Pan'kiv LP. Methodological approaches to the assessment of sheep meat productivity. Collection of scientific works. Zootekhnicheskaya nauka Belarusi. Genetika, razvedenie, 
biotekhnologiya razmnozheniya i vosproizvodstva. Tekhnologiya kormov i kormleniya, produktivnost'. - Zhodino. 2016;51(1):147-54 (in Russian).

29. Lakyn H.F. Biometry. Moscow, Vysshaya shkola. 1990: 352 p. (in Russian).

30. Khederzadeh S, Iranmanesh M, Motamedi-Mojdehi R. Genetic diversity of myostatin and calpastatin genes in Zandi sheep. Journal of Livestock Science and Technologies. 2016;4(1):45-52. doi: 10.22103/JLST.2016. 1381 .

31. Azari AM, Dehnavi E, Yousefi S, Shahmohamadi L. Polymorphism of calpastatin, calpain and myostatin genes in native Dalagh sheep in Iran. M. Slovak J. Anim. Sci. 2012;45(1):1-6.

32. Suleman M, Khan SU, Riaz MN, Yousaf M, Shah A, Ishaq $R$, Ghafoor A. Calpastatin (CAST) gene polymorphism in Kajli, Lohi and Thalli sheep breeds. Afric. J. of Biotechnol. 2012;11(47):10655-660. doi: 10.5897/ AJB11.2478.

33. Iovenko VM, Pysarenko NB, Skrepets KV. Polymorphism of Cast gene in caracul breed of sheep. Scientific bulletin Askaniya-Nova. 2016;(9):58-64 (in Ukrainian).

34. Tohidi R, Elyasi G, Javanmard A, Shoja J, Rezaei R, Pirahary $O$. Molecular analysis of ovine calpastatin gene in six Iranian sheep breeds using PCR-RFLP. J. Mol. Genet. 2010;2(1):6-9. https://doi.org/10.3923/jmolgene. 2010.6.9.

35. Nassiry MR, Tahmoorespour M, Jabadmaneh A, Soltani $M$, Far $S F$. Calpastatin polymorphism and its association with daily gain in Kurdi sheep. Iran. J. Biotchnol. 2006;4(3):188-92.

36. Dagong MIA, Sumantri C, Noor RR, Herman R, Yamin $M$. Growth characteristics of Indonesian Thin Tail Sheep (TTS) based on calpastatin (CAST) gene genotype variation. Adv. Environ. Biol. 2016;10(11):27-31.

37. Wang H, Wang J, Wang $X$, Cheng $S$, Li X, Wang Z, Fan $Q$, $\mathrm{Fu} L$, Li S, Zhou $X$. Association analysis of CAST gene polymorphism with meat quality in five sheep breeds. Acta Agriculturae Zhejiangensis. 2016;28(8):1309-1314.

38. Dagong MIA, Herman R, Sumantri C, Noor RR, Yamin $M$. Carcass and physical meat characteristics of thin tail sheep (TTS) based on calpastatin gene (CAST) (locus intron 5 - exon 6) genotypes variation. J. Ilmu Ternak dan Veteriner. 2012;17(1):13-24.

39. Khan S, Riaz MN, Ghaffar A, Khan MFU. Calpastatin (CAST) gene polymorphism and its association with average daily weight gain in Balkini and Kajli sheep and Beetal goat breeds. Pakistan J. Zool. 2012;44(2):337-82.

40. Jawasreh KI, Jadallah R, Al-Amareen AH, Abdullah AY, Al-Qaisi A, Alrawashdeh IM, Al-Zghoul MBF, Ahamed $M K A$, Obeidat B. Association between MspI calpastatin gene polymorphisms, growth performance, and meat characteristics of Awassi sheep. Indian J. Anim. Sci. 2017;87(5):635-9.

41. Liu GQ, Dai R, Ren HX, Wang XH, Liu SR, Sun YL, Yang $L G$. Polymorphism analysis of genes associated with hindquarters muscular development on chromosome 18 in Xinjiang meat sheep. Yi Chuan. 2006;28(7):815-20. PMID: 16825168.

42. Nanekarani S, Goodarzi M, Mahdavi M. Analysis of Polymorphism of Callipyge Gene in Lori Sheep by PCRRFLP Method. APCBEE Procedia. 2014;8:65-9. doi: 10. 1016/j.apcbee.2014.03.002.

43. Nanekarani S, Goodarzi M. Polymorphism of Candidate Genes for Meat Production in Lori Sheep. IERI Procedia. 2014;8:18-23. doi: 10.1016/j.ieri.2014.09.004.

44. Dimitrova I, Bozhilova-Sakova M. PCR-RFLP analysis of callipyge gene (CLPG) in Karakachan sheep breed. Bulgar. J. Agric. Sci. 2016;22:482-4.

45. Alakilli SYM. Analysis of polymorphism of calpastatin and callipyge genes in Saudi sheep breeds using PCR-RFLP technique. Int. J. Pharmac. Sci. Rev. Res. 2015;30(1):340-4. 